\title{
Aspectos epidemiológicos, biotipologia e evolução do tratamento da leucemia linfocítica aguda na infância e adolescência no Rio Grande do Sul

\author{
Epidemiologic aspects, biotypology and evolution of acute lymphocytic leukemia in childhood and \\ adolescence in Rio Grande do Sul
}

\author{
Waldir Veiga Pereira \\ Orientador: Vicente Odone Filho
}

\section{Resumo}

A leucemia linfocítica aguda na infância e adolescência é uma neoplasia de precursores linfoides de natureza heterogênea. No Brasil, os estudos cooperativos foram iniciados em 1980. Na sequência destes estudos foram observadas sobrevidas livre de eventos de $50 \%, 58 \%$ e $70 \%$ nos protocolos 80,82 e 85 respectivamente. Neste trabalho foram avaliados 1.472 pacientes com LLA, $56,59 \%$ masculinos e $43,41 \%$ femininos, com idades entre 0 e 20 anos, média de 7,40 anos, no período de 1980 a 2008 provenientes do RS. Os dados foram colhidos dos prontuários dos pacientes das principais instituições hospitalares que assistem neoplasias hematológicas pediátricas. Neste estudo, 487 pacientes $(39,40 \%)$ foram registrados nos protocolos do GBTLI; 678 $(54,85 \%)$ receberam tratamento baseados nos regimes do grupo BFM e $71(5,75 \%)$ por outros regimes. A sobrevida livre de eventos dos pacientes protocolados foi significativamente superior comparada aos não protocolados, $62,41 \% \pm 2,43 \%$ e $53,86 \% \pm$ $2,04 \%$ respectivamente, em cinco anos. Pacientes com idade de 15 a 19 anos tiveram um índice de SLE de 37,98\% $\pm 4,72 \%$ em cinco anos, inferior quando comparado aos de 0 a 4 anos e 5 a 9 anos respectivamente: $62,78 \% \pm 2,28 \%$ e $62,43 \% \pm 2,84 \%$. Foi observada, na população estudada, uma SG de $63,73 \% \pm 1,49 \%$ e SLE de $57,27 \% \pm 1,57 \%$. A incidência da LLA com progenitores B seguiu o padrão observado em países desenvolvidos com um pico de frequência absoluta entre as idades de 2 a 4 anos. Houve diferença significativa entre a população da região urbana ou rural: SLE em cinco anos de $61,76 \% \pm 1,76 \%$ e $49,81 \% \pm 4,28 \%$ respectivamente. A SLE e a SG em lactentes e portadores de síndrome de Down foi inferior aos resultados obtidos em instituições dos países desenvolvidos.

Palavras-chave: Leucemia-linfoma linfoblástico de células precursoras; epidemiologia; incidência; análise de sobrevida; protocolos antineoplásicos.

Resumo de tese apresentada à Faculdade de Medicina da Universidade de São Paulo para obtenção do título de Doutor em Medicina.

Correspondência: Waldir Veiga Pereira

Rua Antônio Torronteguy, 52

97110-740 - Santa Maria-RS - Brasil

E-mail: waldirpereira@zipline.com.br

\section{Abstract}

Acute lymphocytic leukemia (ALL) in childhood and adolescence is a neoplastic disease of varied lymphoid precursors. In Brazil, cooperative studies on the treatment of ALL started in 1980. According to these studies, the event free survival (EFS) was $50 \%, 58 \%$ and $70 \%$ in the protocols of 1980,1982 and 1985 , respectively. In this work, 1472 ALL patients were evaluated; $56.59 \%$ were male and $43.41 \%$ were female with ages that ranged between 0 and 20 years old (mean age of 7.4 years old). Data was collected from the records of patients with hematologic neoplasias in medical institutions that offered treatment for pediatric neoplasias in the period from 1980 to 2008. In this study, 487 patients (39.40\%) were registered in the GBTLI protocol; 678 $(54.85 \%)$ received treatment based on the BFM group regimen and $71(5.75 \%)$ were treated according to other regimens. The EFS at five years of the patients on the GBTLI protocol was significantly higher than those who were not on this protocol $(62.41 \% \pm 2.43 \%$ and $53.86 \% \pm 2.04 \%$, respectively). In respect to the age range, the patients who were between 15 and 20 years old had an EFS of $37.98 \% \pm 4.72 \%$ at five years, which is lower than the rate for 0 to 4 -year-old and 5 to 9 -year-old patients $(62.78 \% \pm 2.28 \%$ and $62.543 \pm 2.84 \%$, respectively). An overall survival of $63.73 \% \pm 1.49 \%$ and EFS of $57.27 \% \pm 1.57 \%$ were observed in the studied population. Epidemiologically, the incidence of ALL in B progenitors followed the pattern observed in developed countries with an absolute frequency peak in the age range of 2 to 4 year olds. The outcome was better for patients from urban areas compared to those from rural areas. EFS and overall survival in infant and Down syndrome patients were worse than the results obtained in developed countries.

Key words: Precursor cell lymphoblastic leukemialymphoma; epidemiology; incidence; survival analysis; antineoplastic protocols.

Avaliação: A RBHH publica os resumos e abstracts de teses da área apresentados em entidades que tenham programas de pós-graduação reconhecidos pelo $\mathrm{MEC/Capes} \mathrm{e} \mathrm{considera} \mathrm{a} \mathrm{obtenção} \mathrm{do} \mathrm{título}$ suficiente para sua publicação na forma como se propõe a seção.

Recebido: 28/06/2010

Aceito: 28/06/2010 